\title{
Güç Kalitesi Olay İşaretlerinin LabVIEW ile Üretilmesi ve Doğrulanmasi*
}

\section{Generation and Verification of Signals of Power Quality Events by LabVIEW}

\author{
Mustafa Ercire $^{1^{*}}$, Abdurrahman Ünsal $^{2}$
}

Geliş / Received: 15/07/2021

Revize / Revised: 30/09/2021

Kabul / Accepted: 01/10/2021

\section{ÖZ}

Elektrik güç kalitesini bozan etkenler ekonomik açıdan büyük öneme sahiptir. Güç kalitesinde meydana gelen bozulmaların tespit edilmesi ve çözüm yöntemlerinin geliştirilmesi üzerine son yıllarda yoğun olarak çalışmalar yapılmaktadır. Akademik çalışmaların önemli bir kısmı simülasyon verileriyle gerçekleştirilmektedir. Simülasyon verilerinin nasıl elde edildiğine ilişkin sınırlı sayıda çalışma olmakla birlikte bu çalışmalarda elde edilen verilerin standartlara uygun olup olmadığının hemen hemen hiç denetlenmediği dikkati çekmektedir. Bu çalışmada güç kalitesi problemlerine ait işaretler LabVIEW ortamında üretilmektedir. Üretilen işaretlerin ilgili standartlara uygun olup olmadığını tespit etmek için bir veri doğrulama uygulaması tasarlanarak test edilmiştir. Veri doğrulama uygulaması ilgili standartlarda verilen tanımlara dayalı olarak geliştirilen algoritmaları kullanarak doğrulama yapmaktadır. Elde edilen sonuçlar ile tasarlanan uygulamanın simülasyon yoluyla üretilen işaretlerin doğrulanmasında etkin olarak kullanılabileceği ve güç kalitesi alanındaki akademik çalışmalara katkı sunabileceği değerlendirilmektedir.

Anahtar Kelimeler-Simülasyon, Güç Kalitesi, Güç Kalitesi Bozulmaları, LabVIEW

\begin{abstract}
Factors that deteriorates the quality of electrical power are of great economic importance. In recent years, intensive studies have been carried out on the detection and solutions of power quality problems. An important part of academic studies is carried out with the simulated data. Although there are a limited number of studies on production of simulation data, it is noteworthy that the data used in these studies are almost never checked whether they comply with the standards. In this study, signals of power quality problems are produced in LabVIEW environment. A data validation application was designed and tested to determine whether the produced signals comply with the relevant standards. The data validation application performs validation using algorithms developed based on the definitions of power quality events given in the relevant standards. The obtained results shows that the designed application can be used in the verification of the simulated power quality signals and will contribute to the academic studies on power quality.
\end{abstract}

\section{Keywords- Simulation, Power Quality, Power Quality Disturbances, LabVIEW}

*Bu çalıșma Prof. Dr. Abdurrahman ÜNSAL danıșmanlığında Mustafa ERCIREE tarafından Kütahya Dumlupınar Üniversitesi , Fen Bilimleri Enstitüsü, Elektrik-Elektronik Mühendisliği Anabilim dalında tamamlanan 563865 refarans numaralı yüksek lisans tezinin bir bölümünden üretilmiştir.

1*Sorumlu yazar iletișim: mustafa.ercire@dpu.edu.tr (https://orcid.org/0000-0003-4157-4951)

Bilgisayar Programcılığı, Gediz Meslek Yüksekokulu, Kütahya Dumlupınar Üniversitesi, Gediz, Kütahya, Türkiye

2İletişim: abdurrahman.unsal@dpu.edu.tr (https://orcid.org/0000-0002-7053-517)

Elektrik-Elektronik Mühendisliği, Mühendislik Fakültesi, Kütahya Dumlupınar Üniversitesi, Kütahya, Türkiye 


\section{GİRIŞ}

Elektrik enerjisi üç temel kavram üzerinden ifade edilmektedir. Bunlar frekans, gerilim ve akım bileşenleridir. Elektrik enerjisi sırasıyla üretim, iletim, dağıtım ve tüketim zinciri boyunca frekans, gerilim ve akım bileşenlerinin tümünü içine alacak şekilde güç sistemi olarak adlandırılmaktadır. Teorik olarak güç sisteminden beklenen, frekans ve gerilimin sabit olduğu, gerilim ve akım dalga şekillerinin sinüs işareti biçiminde olduğu durumdur. Elektrik güç sistemi üretimden tüketime uzanan süreç boyunca hem sistem içi hem de sistem dışı çeşitli etkilere maruz kalmaktadır. Elektrik enerjisinin kullanımı yaygınlaştıkça, özellikle yarı iletken temelli aktif elektronik bileşenler içeren aygıtların kullanımının artması ile kullanıcı taraflı bozucu etkiler artış göstermektedir [1]. Güç sistemi bileşenleri için belirli standartların tanımlanmasıyla "Güç Kalitesi" (Power Quality) kavramı ortaya çıkmıştır. Elektrik enerjisi için temel kalite beklentisi kesintisiz, frekans ve gerilim değeri değişmeyen ve uygulandığ 1 aygitlarda zarara yol açmayan bir biçimde olmasıdır. Elektrik enerjisinin kalitesi üreten, ileten, dağıtan ve kullananlar açısından farklı bakış açılarıyla tanımlanabilmektedir.

Üreticiler açısından güç kalitesi sistem güvenilirliğini ifade etmektedir. Donanım üreticileri için güç kalitesi donanımların düzgün çalışmasına elverişli bir seviyede enerji olmaktadır. Diğer taraftan kullanıcılar açısından süreçlerin, işlemlerin ve işletmelerin süreklilik içinde çalışmalarını sağlayacak enerji "kaliteli enerji" olarak düşünülmektedir [2]. Güç sistemi bileşenleri için belirlenen standartların dışında ortaya çıkan ve elektrikle çalışan aygıtların arızalanmasına ve/veya bozulmasına sebep olan durumlar "Güç Kalitesi Bozulması" (Power Quality Disturbance) olarak tanımlanabilir[3]. Bozulmaların doğru tespit edilebilmesi iki açıdan son derece önemlidir. Bunlar bozulmaya yol açan etkenlerin ortadan kaldırılması ve önleyici tedbirlerin alınmasıdır. Her iki açıdan da bozulmaların göz ardı edilemeyecek ekonomik etkilerinin azaltılması mümkündür. Bozulmaların ekonomik etkileri gerek üreticilerin gerekse elektrik üretim ve dağıtım şirketlerinin maliyetlerine doğrudan ve dolaylı olarak yansımaktadır.

Güç kalitesi bozulmalarından kaynaklanan ekonomik maliyetlerden başlıcaları olarak üretim kayıpları, kaynak ve zaman kaybı, yarı-mamul firelerinin oluşması, üretim sürecinin yeniden başlatılması, donanım hasarları, insan sağlığı ve güvenliği ile ilgili sorunlar, çevresel ve finansal yaptırımlar ve diğer ek maliyetler sayılabilir. Dolaylı ekonomik maliyetler olarak ise üretimde yaşanan gecikmeler ve pazar payı kaybından kaynaklanan maliyetler bulunmaktadır [4].

Uluslararası IEEE 1159-2009 IEEE Recommended Practice for Monitoring Electric Power Quality standardında bir güç sisteminin frekans, gerilim ve akımında meydana gelen güç kalitesi bozulmaları 7 ana başlık altında Tablo 1'deki gibi sınıflandırılmıştır. Bu sınıflar süreksiz olaylar (transients), kısa süreli RMS değişimleri (Short Duration RMS Variations), uzun süreli RMS değişimleri (Long Duration RMS Variations), dengesizlik (imbalance), dalga formu bozulması (waveform distortion), gerilim dalgalanmaları (voltage fluctuations) ve güç frekansı değişimleri (power frequency variations) olarak belirlenmiş̧ir [5]. Sınıflandırma yaklaşımı incelendiğinde süreksiz olaylar ve kısa süreli RMS değişimlerinin 1 dakikadan daha kısa süre içinde gerçekleştiği görülmektedir. Uzun süreli RMS değişimleri 1 dakikadan uzun süren bozulmalar için ayrı bir sınıf şeklinde belirlenmiştir. Diğer sınıflarda için birkaç periyottan dakikalar mertebesine kadar tipik bir süre ölçütü belirlenmemiştir. Tipik süre ölçütü belirlenmeyen bu bozulma türleri için daha geniş zaman aralıklarında yapılan ölçümlerden elde edilen sonuçlar zaman aralığında oransal olarak değerlendirilmektedir. Özetle, bozulmaların bazılarının tespit edilmesi anlık olarak yapılması gerekirken anlık olarak tespit edilmesi gerekmeyen bozulma türleri de bulunmaktadır.

$\mathrm{Bu}$ çalışma kapsamında şebeke geriliminde meydana gelen süreksiz olaylar ve kısa süreli RMS değişimleri incelenmektedir. Süreksiz olaylar dürtüsel (impulsive) ve salınımlı (oscillatory) olmak üzere iki alt sınıfa ayrılmaktadır. Kısa süreli RMS değişimleri ise genel olarak gerilim çökmesi (sag), gerilim şişmesi (swell) ve gerilim kesintisi (interruption) olmak üzere üç alt sınıfa ayrılmaktadır. Güç kalitesi bozulmalarının tespiti ve sınıflandırılması üzerine yapılan çalışmalar ağırlıklı olarak veri setlerinin simülasyon yoluyla elde edilmesi, bozulma olaylarının analiz süreçleri ve güç kalitesi izleme araçlarının geliştirilmesi üzerine yoğunlaşmaktadır. Bu işlemler yapılırken donanımsal bileşenlerin yanında LabVIEW, MATLAB/Simulink, Powersim ve ATP-EMTP vb. gibi çeşitli bilgisayar yazılımları da kullanılmaktadır. Geçmişte yapılan çalışmalar gözden geçirildiğinde simülasyon yöntemiyle üretilen sinyallerin yaygın olarak kullanıldığı görülmektedir. Ancak üretilen sinyallerin standartlarda belirtilen nitelikleri taşıyıp taşımadığı ile ilgili sınamanın çoğunlukla göz ardı edildiği ve doğrudan veri işleme teknikleri ile analiz sürecine geçildiği dikkat çekmektedir. Çalışmanın amacı süreksiz olaylar ile kısa süreli RMS değişimlerine ait güç kalitesi sinyallerinin LabVIEW yazılımı kullanılarak üretilmesi ve üretilen sinyallerin IEEE güç kalitesi standartlarına uygun olup olmadığının değerlendirilmesidir. 


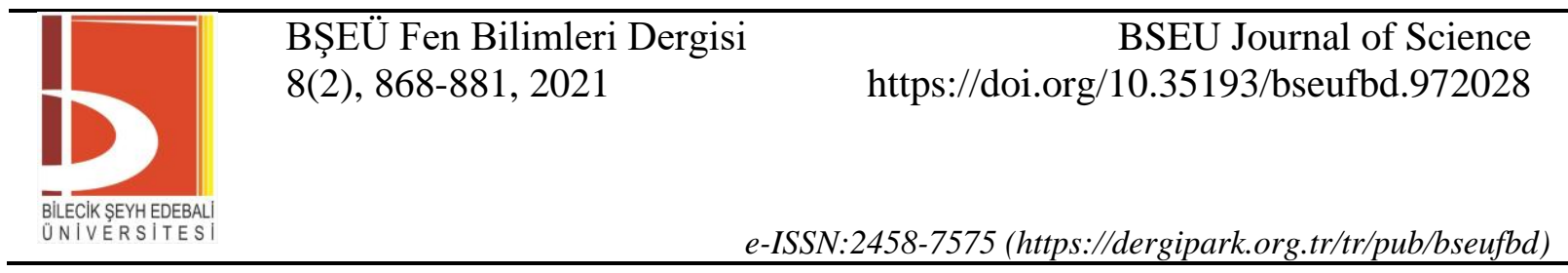

Tablo 1. IEEE 1159-2009 Standardına göre güç kalitesi bozulmaları [5]

\begin{tabular}{|c|c|c|c|}
\hline Kategori & $\begin{array}{c}\text { Tipik } \\
\text { Spektralİçerik }\end{array}$ & Tipik Süre & $\begin{array}{c}\text { Tipik } \\
\text { GerilimGenliği }\end{array}$ \\
\hline \multicolumn{4}{|l|}{ 1. Süreksiz Olaylar } \\
\hline \multicolumn{4}{|l|}{ 1.1. Dürtüsel } \\
\hline 1.1.1. Nano Saniye & 5 ns yükselme & $<50 \mathrm{~ns}$ & \\
\hline 1.1.2. Mikro Saniye & $1 \mu$ s yükselme & $50 \mathrm{~ns}-1 \mathrm{~ms}$ & \\
\hline 1.1.3. Mili Saniye & $0,1 \mathrm{~ms}$ yükselme & $>1 \mathrm{~ms}$ & \\
\hline \multicolumn{4}{|l|}{ 1.2. Salınımlı } \\
\hline 1.2.1. Düşük Frekans & $<5 \mathrm{kHz}$ & $0,3-50 \mathrm{~ms}$ & $0-4 \mathrm{pu}^{\mathrm{a}}$ \\
\hline 1.2.2. Orta Frekans & $5-500 \mathrm{kHz}$ & $20 \mu \mathrm{s}$ & $0-8 \mathrm{pu}$ \\
\hline 1.2.3. Yüksek Frekans & $0,5-5 \mathrm{MHz}$ & $5 \mu \mathrm{s}$ & $0-4 \mathrm{pu}$ \\
\hline \multicolumn{4}{|l|}{ 2. Kısa Süreli RMS Değişimleri } \\
\hline \multicolumn{4}{|l|}{ 2.1. Ani } \\
\hline 2.1.1. Çökme & & $0,5-30$ Periyot & $0,1-0,9 \mathrm{pu}$ \\
\hline 2.1.2. Şişme & & $0,5-30$ Periyot & $1,1-1,8 \mathrm{pu}$ \\
\hline \multicolumn{4}{|l|}{ 2.2. Anlik } \\
\hline 2.2.1. Kesinti & & $0,5-30$ Periyot & $<0,1 \mathrm{pu}$ \\
\hline 2.2.2. Çökme & & 0,5 Periyot $-3 \mathrm{~s}$ & $0,1-0,9 \mathrm{pu}$ \\
\hline 2.2.3. Şişme & & 0,5 Periyot $-3 \mathrm{~s}$ & $1,1-1,4 \mathrm{pu}$ \\
\hline \multicolumn{4}{|l|}{ 2.3. Geçici } \\
\hline 2.2.1. Kesinti & & $>3 \mathrm{~s}-1 \mathrm{dk}$ & $<0,1 \mathrm{pu}$ \\
\hline 2.2.2. Çökme & & $>3 \mathrm{~s}-1 \mathrm{dk}$ & $0,1-0,9 \mathrm{pu}$ \\
\hline 2.2.3. Şişme & & $>3 \mathrm{~s}-1 \mathrm{dk}$ & $1,1-1,2 \mathrm{pu}$ \\
\hline \multicolumn{4}{|c|}{ 3. Uzun Süreli RMS Değişimleri } \\
\hline 3.1. Kesinti, Sürekli & & $>1 \mathrm{dk}$ & $0,0 \mathrm{pu}$ \\
\hline 3.2. Düşük Gerilim & & $>1 \mathrm{dk}$ & $0,8-0,9 \mathrm{pu}$ \\
\hline 3.3. Aşırı Gerilim & & $>1 \mathrm{dk}$ & $1,1-1,2 \mathrm{pu}$ \\
\hline 3.4. Akım Yük Aşımı & & $>1 \mathrm{dk}$ & \\
\hline \multicolumn{4}{|l|}{ 4. Dengesizlik } \\
\hline 4.1. Gerilim & & Kararlı Durum & $0,5-2,0 \%$ \\
\hline 4.2. Akım & & Kararlı Durum & $1,0-30 \%$ \\
\hline \multicolumn{4}{|l|}{ 5. Dalga Biçimi Bozulması } \\
\hline 5.1. DC Ofset & & Kararlı Durum & $0-0,1 \%$ \\
\hline 5.2. Harmonikler & $0-9 \mathrm{kHz}$ & Kararlı Durum & $0-20 \%$ \\
\hline 5.3. Ara Harmonikler & $0-9 \mathrm{kHz}$ & Kararlı Durum & $0-2 \%$ \\
\hline 5.4. Çentik & & Kararlı Durum & \\
\hline 5.5. Gürültü & Genişbant & Kararlı Durum & $0-1 \%$ \\
\hline 6. Gerilim Dalgalanmaları & $<25 \mathrm{~Hz}$ & Aralıklı & $\begin{array}{c}0,1-7 \% \\
0,2-2 \mathrm{P}_{\mathrm{st}}^{\mathrm{b}}\end{array}$ \\
\hline 7. Güç Frekansı Değişimleri & & $<10 \mathrm{~s}$ & $\pm 0,1 \mathrm{~Hz}$ \\
\hline \multicolumn{4}{|c|}{$\begin{array}{l}\text { a pu niceliği birim başına anlamında olup boyutsuzdur. 1,0 pu niceliği \%100’e karşıllık gelmektedir. } \\
\text { Genellikle normal şart } 1,0 \text { pu olarak kabul edilir. Tabloda süreksiz olaylar için referans olarak } \\
\text { normal tepe değeri alınırken RMS değişimleri için ise referans olarak RMS değeri alınmıştır. }\end{array}$} \\
\hline
\end{tabular}

LabVIEW bilim ve mühendislik alanlarında gerçek dünya veri veya sinyalleri üzerinde etkileşimli uygulamalar oluşturmak için oldukça verimli bir geliştirme ortamıdır. LabVIEW ortamında uygulama geliştirme bir nevi yazılım geliştirme sürecidir. Geleneksel yazılım geliştirme yaklaşımında metin tabanlı komutlar kullanılmakta olup kullanıcı ara yüzü tasarımında ise nesne kütüphanelerinde sunulan hazır görsel ögelerden faydalanılmaktadır. LabVIEW ile yazılım tasarımında geleneksel yöntemlerden faklı olarak metin tabanlı kod yazımı yerine grafiksel bir dil kullanılmaktadır. LabVIEW ile geliştirilen uygulamalar iki ana kısımdan oluşmaktadır. Bunlar kullanıcı ile etkileşimin sağlandığı ara yüz yapısını oluşturan "Ön Panel" (Front Panel) ve uygulamanın G dili ile oluşturulduğu "Blok Diyagram" (Block Diagram) kısımlarıdır. Blok diyagramlar işlevleri ve kısaca VI (Virtual Instruments) olarak adlandırılan sanal araçları içermektedir. LabVIEW üzerinde standartlaşmış ve sıkça kullanılan birçok veri işleme eylemi için hazır VI paketleri bulunmaktadır. VI yapıları birbirlerine bağlantılı olarak kullanılabilmekte ve içlerinde başka VI yapıları da barındırabilmektedirler. Aynı zamanda geliştirici tarafından ihtiyaca yönelik olarak VI tasarımları yapılabilmektedir. VI yapıları çok büyük ve karmaşık diyagramlar yerine daha anlaşılır ve karmaşıklığı azaltılmış uygulamalar geliştirmek için avantaj sağlamaktadır. Ön panel ise uygulamanın kullanıcı/araştırmacı ile buluşan yüzüdür. Bu alana düğmeler, grafikler, ibre ve kadran yapıları, göstergeler vb. gibi hazır ögeler yerleştirilmektedir. Bu sayede uygulamanın işletilmesinin yanısıra veri üzerinde süregiden işlemler ve elde edilen sonuçlar gözlemlenebilmektedir. Bu özellikleri ile Ön Panel tek taraflı bir sonuç/durum görüntüleme ortamının ötesinde kullanıcı/araştırmacının sürece müdahale 
edebilmesini sağlayan etkileşimli bir ortamdır. LabVIEW ortamında yazılım geliştirme amacıyla sunulan hazır yapılara ilişkin örnek bir görsel Şekil 1'de verilmiştir.

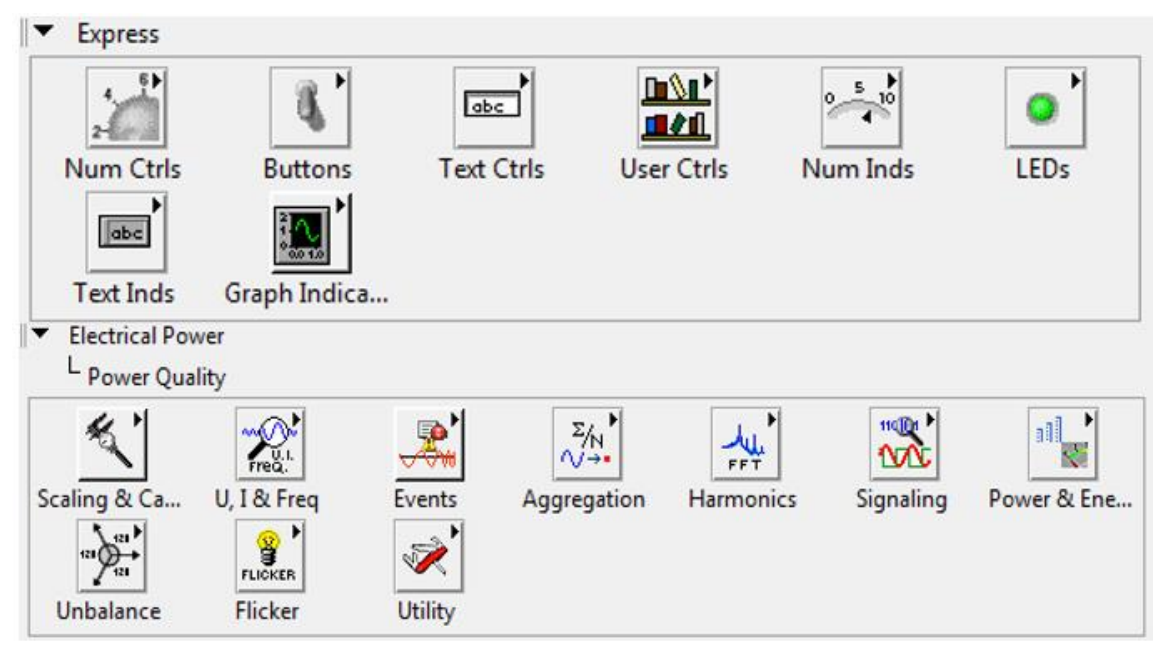

Şekil 1. LabVIEW ortamında sunulan hazır bileşenler

Geçmişte güç kalitesi alanında LabVIEW kullanılarak yapılıış çalışmalar bulunmaktadır. Bath ve Kumra, LabVIEW ile harmonik, gürültü ve süreksiz olayların simülasyonu ve ölçülmesi üzerinde çalışmışlardır [6]. Yin ve Chilukuri, LabVIEW ile gerilim ve akımın gerçek zamanlı izlenmesini sağlayan bilgisayar tabanlı bir veri toplama sistemini geliştirmişlerdir [7]. Laskar ve Muhammad, LabVIEW yazılımı ile sanal enstrümanlar tasarlayarak basit bir güç kalitesi izleme sisteminin geliştirilmesinin ön çalışmalarını yapmışlardır [8]. Pradhan ve arkadaşları, LabVIEW kullanılarak anlık güç, aktif ve reaktif güç, güç faktörü ve harmonikler gibi güç kalitesi parametrelerini izleme sistemi geliştirmişlerdir [9]. Simić ve arkadaşları, LabVIEW ile bilgisayar tabanlı sanal enstrüman ve güç amplifikatöründen oluşan elektriksel güç kalitesi sinyal üretecinin uygulanmasını önermişlerdir [10]. Simić ve arkadaşları, LabVIEW ile gerçek elektrik güç dağıtım ağlarında tipik olan çeşitli güç kalitesi bozulmalarının simülasyonu için olasılık dahil olmak üzere standart üç fazlı voltaj dalga biçimlerinin üretilmesini gerçekleştirmişlerdir [11]. Chunling ve arkadaşları, LabVIEW ile gerilim şişmesi, çökmesi, dalgalanmaları ve salınımlar gibi geçici bozulma sinyalleri üretecini ve detektörünü içeren bir geçici güç kalitesi dedektif platformunu gerçek zamanlı algılamayı gerçekleştirmek için Hilbert faz kaydırmalı Dönüşüm yöntemini kullanarak geliştirmişlerdir [12]. Khadse ve arkadaşları, LabVIEW ile bilgisayar tabanlı gerçek zamanlı güç kalitesi izleme sistemi geliştirerek bozulmaların gerçek zamanlı tespiti ve arızaların sınıflandırılmasına çalışmışlardır [13]. Nadhiroh ve Aji, LabVIEW kullanarak üç fazlı akım ve gerilimin dalga biçimini, frekansı, güç faktörünü, RMS değerini ve toplam harmonik bozulmayı görüntüleyen ve web tabanlı çevrimiçi izlenmesine olanak veren sistemi geliştirmişlerdir [14]. Velkovski ve Kokolanski, güç kalitesi bozulmalarının farklı türleri ve kombinasyonlarını çeşitli sürelerde üretme ve bunları donanım üzerinde yeniden üretebilme ve kaydetme yeteneğine sahip sistemi LabVIEW üzerinde geliştirmişlerdir [15]. Dekhandji ve arkadaşları, güç kalitesi bozulmalarının tespiti ve sınıflandırılması için Hilbert ve Dalgacık dönüşümleri ile gelişmiş sinyal işleme araçlarını ve Yapay Sinir Ağı ve Destek Vektör Makinesi gibi yapay zeka araçlarını kullanarak güç kalitesi analizini LabVIEW üzerinde gerçekleştirmişlerdir [16]. LabVIEW ile endüstriyel tüketici güç kalitesinin analizi için sanal enstrümantasyona dayalı bir sistem tasarlayarak 3 faz gerilim ve akım verilerini ve güç parametrelerini toplayan ve hesaplayan izleme aracı geliştirmişlerdir [17].

Bu çalışmada amaç, güç sistemi bileşenlerinden gerilim üzerinde oluşan kısa süreli güç kalitesi bozulması olay işaretlerinin LabVIEW yazılımı ile üretilmesi ve doğrulanmasıdır. Güç kalitesi bozulması olay işaretleri tanımlarına uygun olarak matematiksel denklemlere dayalı simülasyon yöntemiyle üretilmiştir. Üretilen olay işaretlerinin doğruluğunun sınanması amacıyla bir sınıflandırma algoritması geliştirilmiştir. Güç sistemlerinde elektriksel gürültü (noise) bulunması da dikkate alınarak üretilen işaretlerin elektriksel gürültü içermesi durumunda sınıflandırmanın doğruluğu analiz edilmiştir. 


\begin{tabular}{|c|c|c|}
\hline & $\begin{array}{l}\text { BŞEÜ Fen Bilimleri Dergisi } \\
8(2), 868-881,2021\end{array}$ & $\begin{array}{r}\text { BSEU Journal of Science } \\
\text { https://doi.org/10.35193/bseufbd.972028 }\end{array}$ \\
\hline $\begin{array}{l}\text { BiLECIKSEYHEDEBALI } \\
\text { UNIVERSITESI }\end{array}$ & & 2458-7575 (https://dergipark.org.tr/tr/pub/bseufbd) \\
\hline
\end{tabular}

\section{MATERYAL VE YÖNTEM}

\section{A. Güç Kalitesi Olay İşaretlerinin Üretilmesi}

Bozulma olayları üzerinde yapılacak çalışmalarda kullanılacak verileri elde etmek için farklı yaklaşımlar bulunmaktadır. Kaydedilmiş gerçek olay verileri, simülasyon yoluyla elde edilmiş olay verileri ve sayısal modele dayalı elde edilmiş olay verileri bu yaklaşımlara örnek olarak verilebilir. Matematiksel model olarak da adlandırılan sayısal model bozulmalar üzerinde yapılan çalışmalarda sıklıkla tercih edilmektedir. Sayısal modelin en belirgin avantajlarından bir tanesi matematiksel denklemlerin parametrik yapıya sahip olmalarıdır. Bu yapıda parametreler bir nevi değişken olarak düşünülebilir ve değişkenler veri üretimine esneklik kazandırmaktadır.

Çalışma kapsamında incelenen olay işaretleri anlık olarak tespit edilmesi gereken bozulma türlerindendir. Bunlar olay içermeyen normal durum, dürtüsel süreksiz olay, salınımlı süreksiz olay, gerilim çökmesi, gerilim şişmesi ve gerilim kesintisi bozulmaları içeren olay işaretleri olarak belirlenmiştir.

Seçilen bozulmalar temelde iki farklı ana başlık altında incelense de ortak karakteristik özellik olarak bozulmanın süresi öne çıkmaktadır. Gerek süreksiz olaylar gerekse kısa süreli RMS değişimleri bir periyottan kısa süreli olabilmekte ve aynı zamanda birkaç periyoda yayılabilmektedir. Dürtüsel süreksiz olaylar yarım periyottan daha kısa sürelerde gerçekleşmektedirler. Salınımlı süreksiz olaylar salııım frekansına bağlı olmak üzere en fazla $50 \mathrm{~ms}$ sürmektedirler. Bu süre $50 \mathrm{~Hz}$ şebeke frekansında 2,5 periyoda karşılık gelmektedir. RMS değişimine bağlı olarak sınıflandırılan olaylarda ise en kısa olay süresi yarım periyot olarak tanımlanmıştır. Olay türlerinin tipik özelliklerine süre açısından bakıldığında olayların benzer süreler içinde gerçekleştikleri görülmektedir.

Şebeke gerilimi dalga formu sinüs işareti temelinde üretilmiştir. Dalga formunun süresi 12 tam periyot olarak belirlenmiştir. Toplam 12 periyotluk süre içerisinde ilk ve son periyotlar olay içermeyecek şekilde tasarlanırken arada kalan 10 periyotluk süre ise olayı içerecek șekilde tasarlanmıştır. Olay bölgesini oluşturan 10 periyotluk süre belirlenirken süreksiz olayların ve kısa süreli RMS değişimlerinin Tablo 1'de verilen başlama ve sona erme süreleri dikkate alınmıştır. Şekil 2'de üretilen dalga formlarının şablonu verilmiştir.

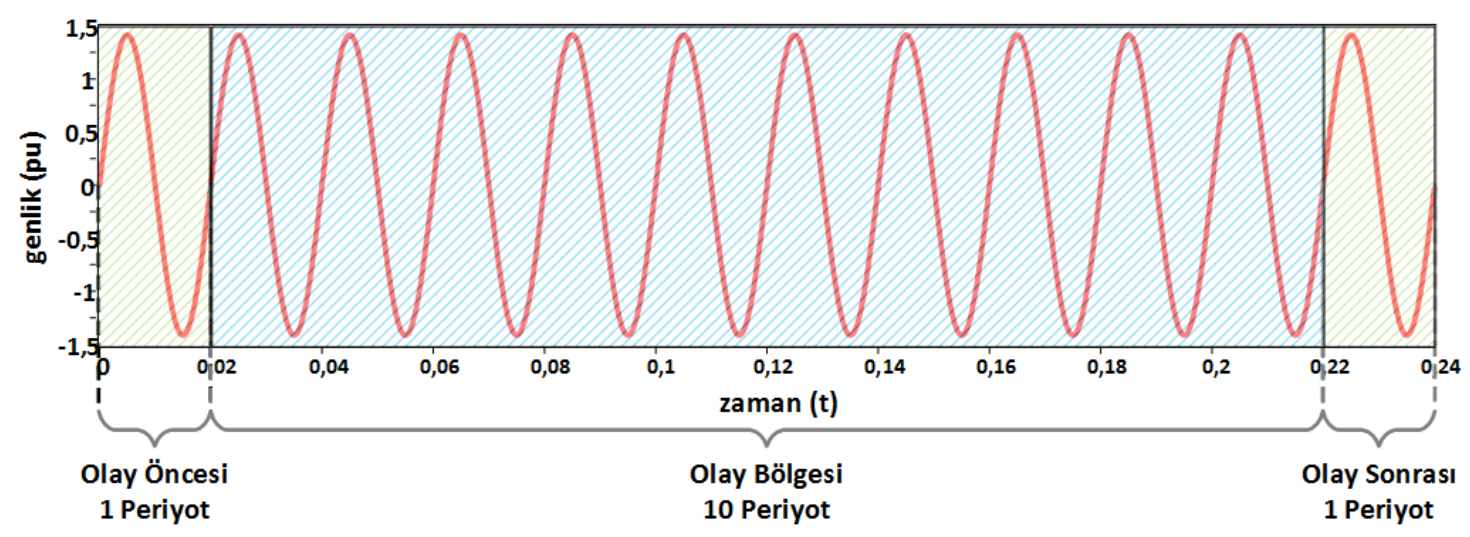

Şekil 2. Bozulma olay işaretleri için dalga formu şablonu

Olay işaretlerinin üretilmesinde örnekleme frekansı $12,8 \mathrm{kHz}$ olarak belirlenmiştir. Örnekleme frekansının belirlenmesinde süreksiz olayların frekans bileşenleri dikkate alınmıştır. Düşük frekanslı süreksiz olaylar en fazla $5 \mathrm{kHz}$ salınım frekansına sahiptir. $5 \mathrm{kHz}$ frekans bileşeni içerebilen işaretin Nyquist Teoremi gereği en az iki katı frekansla örneklenmesi gerektiği dikkate alınmıştır. Üretilen olay işaretleri sabit $50 \mathrm{~Hz}$ frekansa ve 1,0 pu RMS değere sahiptir. Seçilen örnekleme frekansı aynı zamanda pek çok güç kalitesi analizörü yazılımı ve donanımı tarafindan da kullanılmaktadır.

Bu çalışmada bozulma olay işaretleri sayısal modele dayalı olarak elde edilmiștir. Çalışmada kullanılan denklemler [18]'de geliştirilen matematiksel denklemlere uygun olacak biçimde uyarlanarak kullanılmıştır. Uyarlanan matematiksel denklemler ve parametreler Tablo 2'de verilmiştir.

RMS değişimine bağlı bozulma içeren olay işaretlerinin üretilmesinde RMS değerine etki eden bir $\alpha$ katsayısı kullanılmışır. Bu katsayı çökme olayında 0,12 ile 0,88 pu arasında, şişme olayında 0,12 ile 0,8 pu arasında, kesinti olayında ise 0,92 ile 1,0 pu arasında bir değer almaktadır. Bu $\alpha$ katsayısının değer aralıkları belirlenirken olay türleri eşik değerleri arasında 0,02 pu aralık bırakılmıştır. Olayın başlangıç ve bitiş anlarını 
sırasılyla $t_{1}$ ve $t_{2}$ parametreleri belirlemektedir. Süre parametreleri olan $t_{1}$ ve $t_{2}, 12$ periyot uzunluğundaki dalga formunun ilk ve son periyotlarında olmamak üzere ve $t_{1}<t_{2}$ şartını sağlayacak şekilde değer almaktadır. $\alpha$ katsayısı, $t_{1}$ ve $t_{2}$ parametreleri her bir olay için rastgele olacak şekilde oluşturulmaktadır.

Dürtüsel ve salınımlı süreksiz olay denklemlerinin her ikisinde de kullanılan $t_{1}$ parametresi olayın başlangıç anını, $\alpha$ parametresi 0,3 - 1 pu arasında genliğini, $\rho$ parametresi ise süreksizliğin sönümlenme süresini belirlemektedir. Salınımlı süreksiz olay denkleminde $\omega_{o}$ parametresi $0,5-4,5 \mathrm{kHz}$ aralığında salınım frekansını belirlemektedir. $t_{1}$ parametresi etkin değer değişimine bağlı olay türlerinde olduğu gibi yine 10 periyotluk olay bölgesi içinde değer almaktadır.

Tablo 2. Bozulma olay işaretlerinin matematiksel denklemleri.

\begin{tabular}{|c|c|c|}
\hline Sinıf & Denklem & Parametreler \\
\hline Normal & $V(t)=A * \sin (\omega t)$ & $\begin{array}{c}A=\sqrt{2}(1 p u R M S) \\
\omega=2 \pi f \\
f=50 \mathrm{~Hz}\end{array}$ \\
\hline $\begin{array}{l}\text { Gerilim } \\
\text { Çökmesi }\end{array}$ & $V(t)=A *\left(1-\alpha\left(u\left(t-t_{1}\right)-u\left(t-t_{2}\right)\right)\right) * \sin (\omega t)$ & $\begin{array}{c}T<t_{1}<10,5 T \\
T / 2 \leq\left(t_{2}-t_{1}\right) \leq 10 T \\
0,12 \leq \alpha<0,88\end{array}$ \\
\hline $\begin{array}{l}\text { Gerilim } \\
\text { Şişmesi }\end{array}$ & $V(t)=A *\left(1+\alpha\left(u\left(t-t_{1}\right)-u\left(t-t_{2}\right)\right)\right) * \sin (\omega t)$ & $\begin{array}{c}T<t_{1}<10,5 T \\
T / 2 \leq\left(t_{2}-t_{1}\right) \leq 10 T \\
0,12 \leq \alpha<0,8\end{array}$ \\
\hline $\begin{array}{l}\text { Gerilim } \\
\text { Kesintisi }\end{array}$ & $V(t)=A *\left(1-\alpha\left(u\left(t-t_{1}\right)-u\left(t-t_{2}\right)\right)\right) * \sin (\omega t)$ & $\begin{array}{c}T<t_{1}<10,5 T \\
T / 2 \leq\left(t_{2}-t_{1}\right) \leq 10 T \\
0,92 \leq \alpha<1,0\end{array}$ \\
\hline Dürtüsel & $V(t)=A * \sin (\omega t)+\alpha\left(u\left(t-t_{1}\right) *\left(e^{-\left(\left(t-t_{1}\right) * \rho\right)}\right)\right)$ & $\begin{array}{c}T<t_{1}<10,5 T \\
0,3 \leq \alpha<1,0 \\
1000<\rho<3600\end{array}$ \\
\hline Salınımlı & $V(t)=A * \sin (\omega t)+\alpha\left(u\left(t-t_{1}\right) * \sin \left(\omega_{o} t\right) *\left(e^{-\left(\left(t-t_{1}\right) * \rho\right)}\right)\right)$ & $\begin{array}{c}T<t_{1}<9 T \\
0,3 \leq \alpha<1,0 \\
250<\rho<2250 \\
\omega_{o}=2 \pi f_{o} \\
500<f_{o}<4500\end{array}$ \\
\hline
\end{tabular}

Matematiksel denklemlerle modellenerek oluşturulan bozulma olaylarından istenilen sayıda üretilerek veri seti hazırlamak amacıyla "LabVIEW Veri Seti Hazırlama" uygulaması tasarlanmıştır. Hazırlanan ara yüz ile oluşturulmak istenen veri seti için bir isim verilmesi ve her bir olaydan kaç adet hazırlanacağının belirtilmesi sağlanmıştır. Veri Hazırlama uygulamasının ön panelinde yer alan bileşenlerden örnekler ve parametreleri Şekil 3'de verilmiştir. Ön Panelde olay işaretlerine ilişkin örnekleme frakansı, frekans, faz açısı, periyot sayısı, genlik ve olay bölgesi genel parametreler olarak gruplanmıştır. Olaya özgü parametre olarak seviye ve olay bölgesinin rastgele belirlenebilmesinin yanında isteğe bağlı belirleme olanağı da verilerek olay izleme işlevi de görmesi amaçlanmıştır.

Güç sistemlerinde belirli seviyelerde gürültü bulunur. Bir güç sistemindeki kabul edilebilir gürültü nominal genlik değerinin yaklaşık \%0,7 ila \%0,9 oranında genlikte olup $50 \mathrm{~dB}$ ila $48 \mathrm{~dB}$ arasındadır [16]. Gürültü bozulmaların tespitinde başarıma etki eden önemli parametrelerden bir tanesidir. Bundan dolayı her bir olay işareti gürültüsüz, $50 \mathrm{~dB}$ düşük seviye, $40 \mathrm{~dB}$ orta seviye ve $30 \mathrm{~dB}$ yüksek seviye gürültülü olarak üretilerek veri setleri oluşturulmuştur. Gürültü işareti olarak literatürde sıklıkla kullanılan "Gaussian White Noise" kullanılmıştır. "LabVIEW Veri Seti Hazırlama" uygulaması ile oluşturulmuş bir veri setinde olaylar aynı olmak üzere farklı gürültü seviyelerinde 4 adet alt veri seti hazırlanmıştır. "LabVIEW Veri Seti Hazırlama" uygulaması ile üretilen olay işaretleri Şekil 4'de gösterilmiştir.

\section{B. Güç Kalitesi Olay İşaretlerinin Doğrulanması}

Oluşturulan veri setindeki olayların tanımlarına uygun olarak üretilip üretilmediklerini doğrulamak amaciyla "LabVIEW Veri Seti Doğrulama" uygulaması geliştirilmiştir. Bu uygulamada incelenen tüm olay türleri için geçerliliğe sahip olacak şekilde bir algoritma geliştirilmiş ve kullanılmıştır. Bozulma olaylarının tespitinde IEC 61000-4-30 Testing and Measurement Techniques - Power Quality Measurement Methods standardına uygun şekilde geliştirilen yöntemler kullanılmıştır [19]. Bozulma olayı tespitinde öncelikli yaklaşım RMS değişiminden kaynaklı bir olay olup olmadığının incelenmesidir. Zaman zaman yüksek genlikli süreksiz bir olay eşik değerleri aşan RMS değişimine de neden olabilmektedir. Bu durum çoklu bozulma olarak değerlendirilmektedir. Bu 


\begin{tabular}{|c|c|c|}
\hline & $\begin{array}{l}\text { BŞEÜ Fen Bilimleri Dergisi } \\
8(2), 868-881,2021\end{array}$ & $\begin{array}{r}\text { BSEU Journal of Science } \\
\text { https://doi.org/10.35193/bseufbd.972028 }\end{array}$ \\
\hline ERS & & :2458-7575 (https://dergipark.org.tr/tr/pub/bseufbd) \\
\hline
\end{tabular}

durumda öncelikle RMS değişimine bağlı bozulmalar araştırılmaktadır. Şayet böyle bir bozulma görülmüyorsa süreksiz olay incelemesi yapılmaktadır.
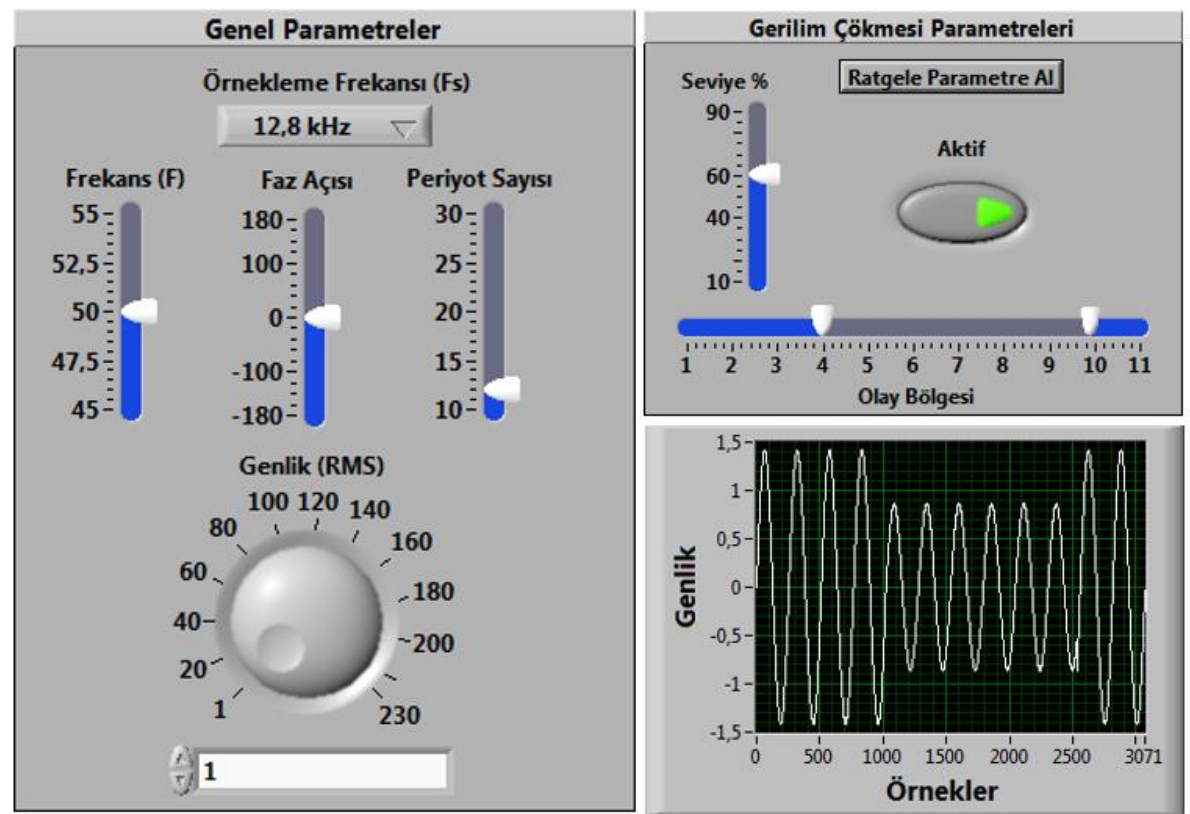

Şekil 3. LabVIEW veri hazırlama uygulaması ön panel bileşenleri
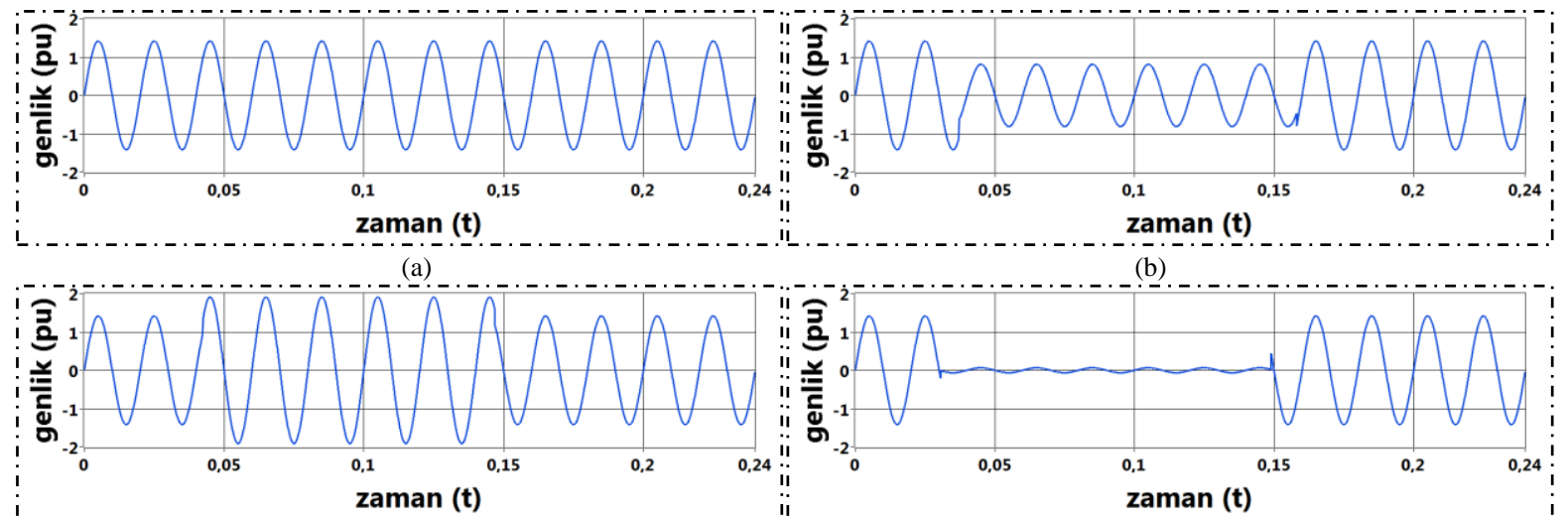

(b)

(c)

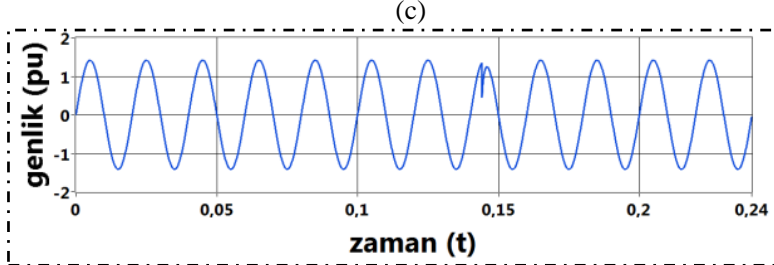

(e)

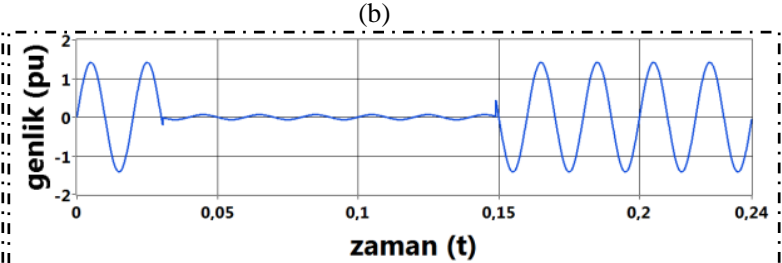
(d)

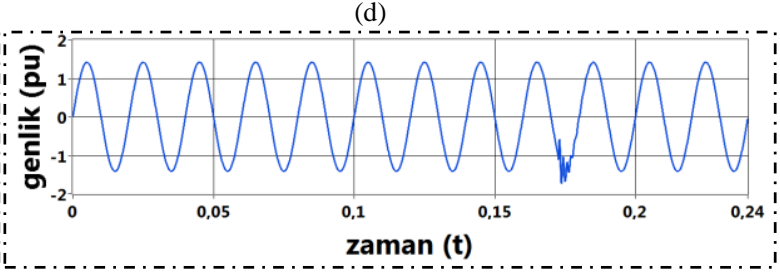

(f)

Şekil 4. Bozulma olay işaretleri: (a) Normal durum, (b) Gerilim çökmesi, (c) Gerilim şişmesi, (d) Gerilim kesintisi, (e) Dürtüsel süreksiz olay, (f) Salınımlı süreksiz olay

Geliştirilen algoritmanın temel işleyişi Şekil 5'de verilmiştir. Bu algoritmada ilk olarak olay işaretinden en büyük ve en küçük RMS değerleri elde edilmektedir. Elde edilen bu değerler Tablo 1'de verilen olay eşik değerleri ile karşılaştırılarak RMS olayının oluşup oluşmadığı incelenmektedir. Eğer RMS değerlerinde birden fazla olaya ilişkin eşik değerlerinin aşıldığı bir durumla karşılaşılırsa bu olay işareti hatalı kabul edilerek inceleme dışı bırakılmaktadır. Eğer olay işareti RMS değişimine bağlı bir bozulma içermiyorsa normal olarak etiketlenmektedir. Algoritmanın bundan sonraki aşaması olay işaretinin süreksiz olay içerip içermediğinin 
incelenmesidir. Bunun için olay işaretinin bozulma içermeyen ilk periyodundan faydalanılarak artı ve eksi değerli en büyük ve en küçük tepe değerleri elde edilir. Elde edilen tepe değerlerinin incelenmesi ile olay işaretinin süreksiz olay içerip içermediği belirlenerek olay işareti etiketlenir. Algoritmanın alt aşamaları bundan sonra açıklanacaktır.

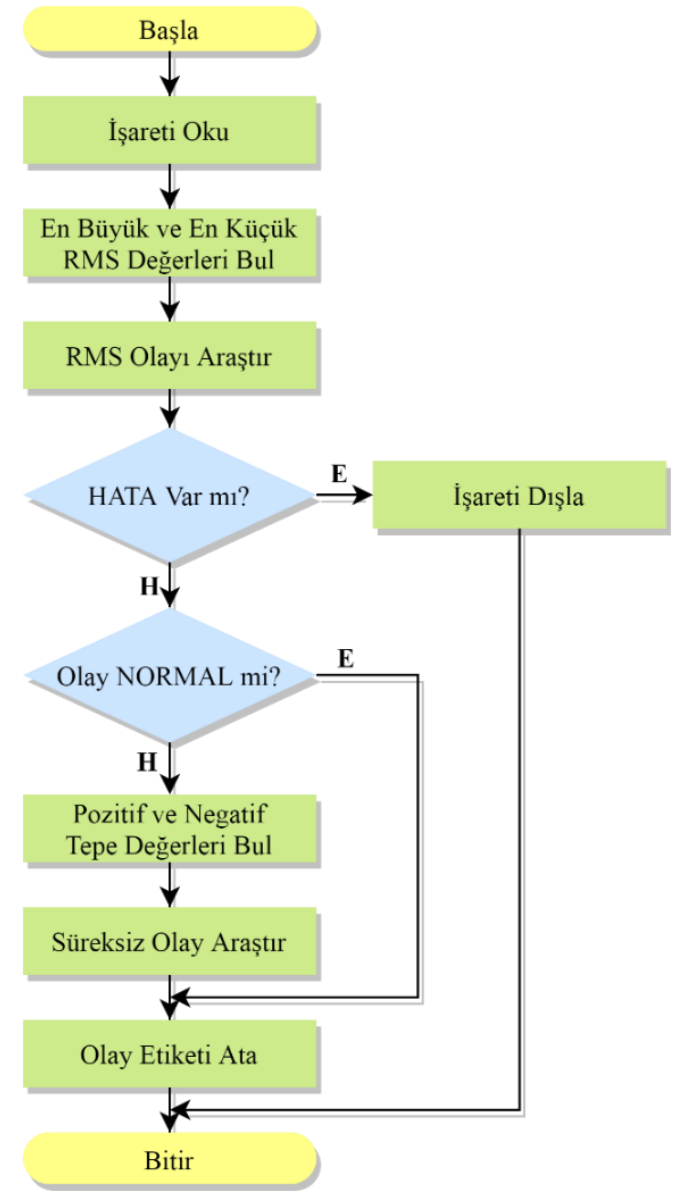

Şekil 5. "LabVIEW Veri Seti Doğrulama” uygulaması ana algoritması

En büyük ve en küçük RMS değerlerinin elde edilmesi için geliştirilen algoritma Şekil 6'da verilmiştir. Çalışma kapsamında incelenen bozulmalardan gerilim çökmesi, gerilim şişmesi ve gerilim kesintisi olayları RMS değişimine bağlı olarak değerlendirilmektedir. İncelenen bozulma olayı işaretlerinin yapısı gereği ilk periyotta hiçbir bozulma bulunmamaktadır. Bu yapıdan yola çıkılarak ilk periyot üzerinden hesaplanan RMS değerleri en büyük ve en küçük başlangıç RMS değerleri olarak atanmaktadır. Daha sonra her yarım periyotta bir olmak üzere 1 tam periyotluk RMS değerleri hesaplanır. Her yarım periyotta bir hesaplanan RMS değeri en büyük RMS değerinden büyük ise yeni en büyük RMS değeri olarak atanırken en küçük RMS değerinden küçük ise yeni en küçük RMS değeri olarak atanır. Bu şekilde olay işaretinin en büyük ve en küçük RMS değerleri elde edilmiş olmaktadir.

İncelenen işarette RMS olayı olup olmadığını araştırmak için geliştirilen algoritma Şekil 7'de verilmiştir. Bu aşamada en büyük ve en küçük RMS değerleri Tablo 1'de verilen eşik değerleri ile karşılaştırılarak incelenen olay işaretinin RMS olayı içerip içermediği araştırılmaktadır. Aynı zamanda incelenen olay işaretinin hatalı olup olmadığı da denetlenmektedir. Bu denetlemede en büyük ve en küçük RMS değerlerinin birden fazla eşik değeri aşarak birden çok olayın karakteristiklerini göstermesi durumunda incelenen olay işareti hatalı olarak etiketlenmektedir. Eğer incelenen olay işareti hata veya herhangi bir RMS olayı içermiyorsa olay normal olarak etiketlenmektedir. 
Süreksiz olaylar dürtüsel ve salınımlı olmak üzere iki alt sınıfa ayrılmaktadır. Bu ayrım süreksiz olayı oluşturan saf bileşene dayalı bir tanımlamadır. Basitçe ifade etmek gerekirse, saf bileşen teorik olarak olay işaretinden temel frekans bileşeninin uzaklaştırılması sonucu elde edilen ve süreksiz olaya ait işareti içeren kısımdır.

Süreksiz olay incelemesinin ilk aşaması olan en büyük ve en küçük tepe değerlerinin elde edilmesi için geliştirilen algoritma Şekil 8'de verilmiştir. Burada öncelikle saf bileşenin elde edilmesi amaçlanmıştır. Saf bileşenin elde edilmesi olay işaretinin kayıt yapısına dayalı geliştirilen bir mantıkla yapılmaktadır. Daha önce de açıklandığı üzere 12 periyotluk olay işaretinin ilk ve son periyotları herhangi bir olay içermemektedir. İlk ve son periyot arasında kalan 10 periyotluk kısımdaki her periyottan ilk periyot çıkarılarak ilgili saf bileşen elde edilmektedir. Elde edilen bu saf bileşenin en küçük (negatif) ve en büyük (pozitif) değerleri saf bileşenin tepe değerlerini ifade etmektedir.

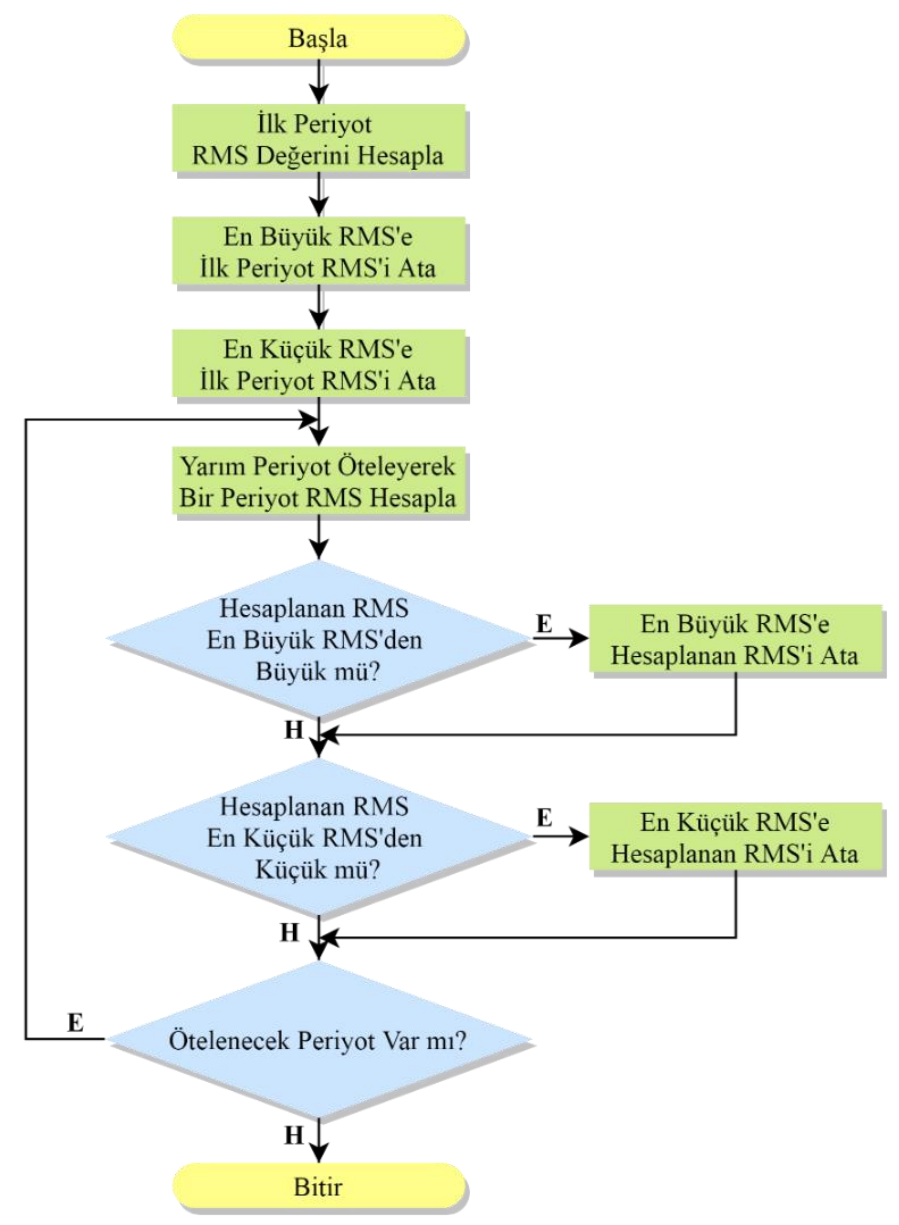

Şekil 6. En büyük ve en küçük RMS değerlerinin elde edilmesi algoritması

İncelenen işarette süreksiz olay olup olmadığını araştırmak için geliştirilen algoritma Şekil 9'da verilmiştir. Bir önceki adımda saf bileşen üzerinden elde edilen en büyük ve en küçük tepe değerlerine bağlı olarak bir değerlendirme yapılmaktadır. Süreksiz olaylarda Tablo 1'den görüleceği üzere genlik değeri için alt limit belirlenmemiştir. Bu noktada olay işareti üzerindeki harmonikler ve gürültü etkileri göz önüne alınarak genlik için 0,15 pu alt limiti uygulanmıştır. Saf bileşenin tepe değerlerinin her ikisi de 0,15 pu'dan daha düşük bir genliğe sahip ise olay işaretinin süreksiz olay içermediği kabul edilmiştir. Eğer tepe değerlerinin herhangi birisi ve/veya her ikisi birden 0,15 pu'dan daha fazla genliğe sahip ise o zaman olay işaretinin süreksiz olay içerdiği varsayılmıştır. $\mathrm{Bu}$ durumda süreksiz olayın dürtüsel mi yoksa salınımlı mı olduğuna karar verilmesi gerekmektedir. 
Süreksiz olaylar ürettikleri işaretin dalga biçimi üzerinden teorik olarak kolayca sınıflandırılabilmektedir. Pozitif veya negatif yönlü ve ani tek bir yükseliş/düşüş darbesi biçimindeki dalga dürtüsel olarak tanımlanmıştır.Her iki polaritede ardışı ve hızlı biçimde değişerek sönümlenen dalga biçimi salınımlı olarak tanımlanmıştır. Ancak gerçek şebeke işaretleri her iki dalga biçimi karakteristiğini de sergileyebilmektedir.

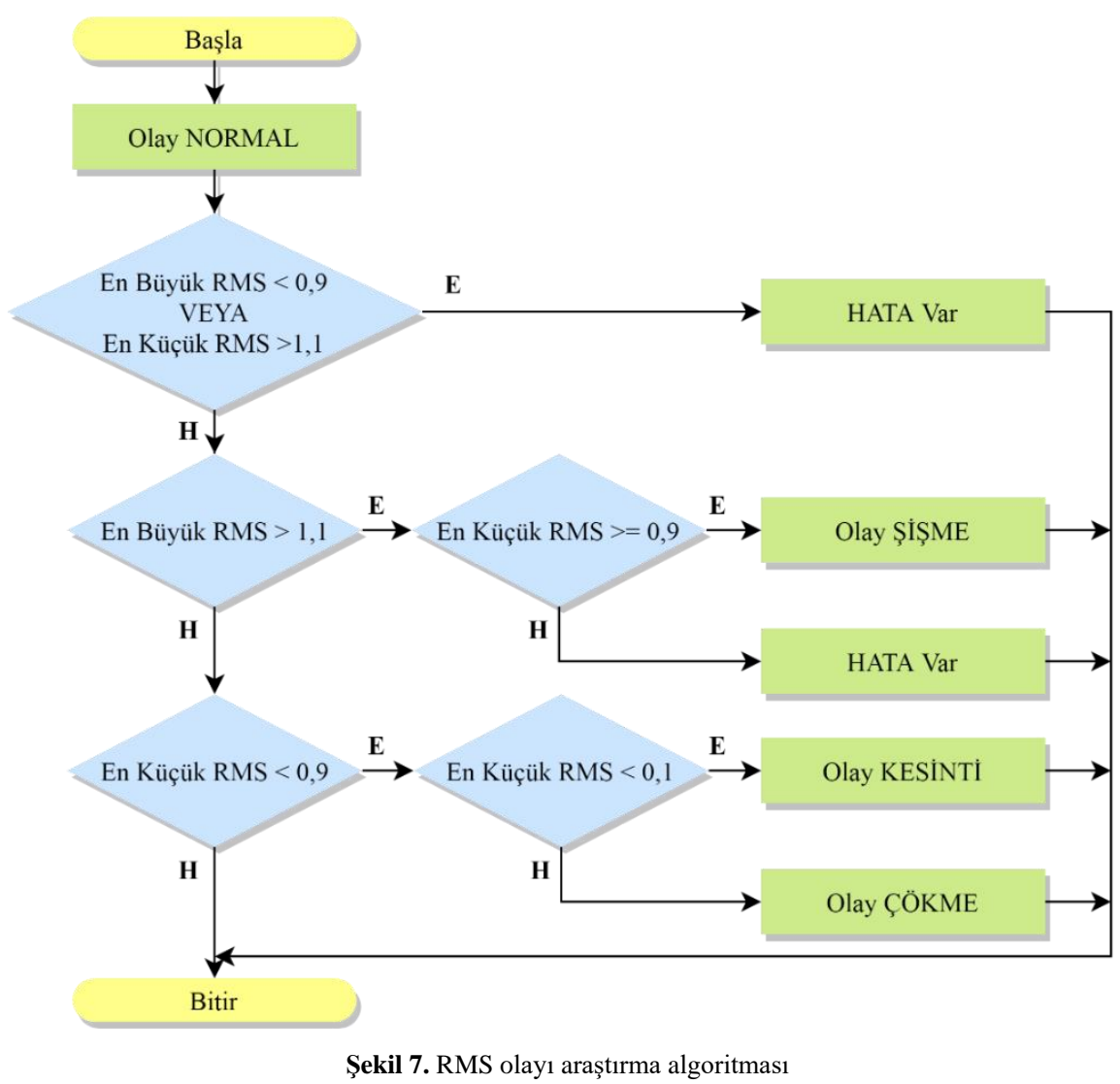

Süreksiz bir olaya ait saf bileşenin tepeden tepeye (peak-to-peak) genlik değerinin \%77 ve daha fazlası tek yönlü polariteye sahipse süreksiz olay dürtüsel olarak kabul edilir aksi halde salınımlıdır. Bu yaklaşımla süreksiz olayların basit bir oransal değerlendirmeyle sınıflandırılabilmeleri sağlanmaktadır. Oransal yaklaşıma bağlı olarak mutlak değeri daha büyük olan tepe değerinin tepeden tepeye değere oranlanmasıyla süreksiz olayın polarite oranı hesaplanmıştır. Hesaplanan oran \%77'den daha büyük ise dürtüsel aksi halde salınımlı süreksiz olay kararına varılarak incelenen olay işareti etiketlenmektedir. 


\begin{tabular}{|c|c|c|}
\hline & $\begin{array}{l}\text { BŞEÜ Fen Bilimleri Dergisi } \\
8(2), 868-881,2021\end{array}$ & $\begin{array}{r}\text { BSEU Journal of Science } \\
\text { https://doi.org/10.35193/bseufbd.972028 }\end{array}$ \\
\hline $\begin{array}{l}\text { BilEECIKEEYHEDEBALI } \\
\text { UNIVERSITESI }\end{array}$ & & 2458-7575 (https://dergipark.org.tr/tr/pub/bseufbd) \\
\hline
\end{tabular}

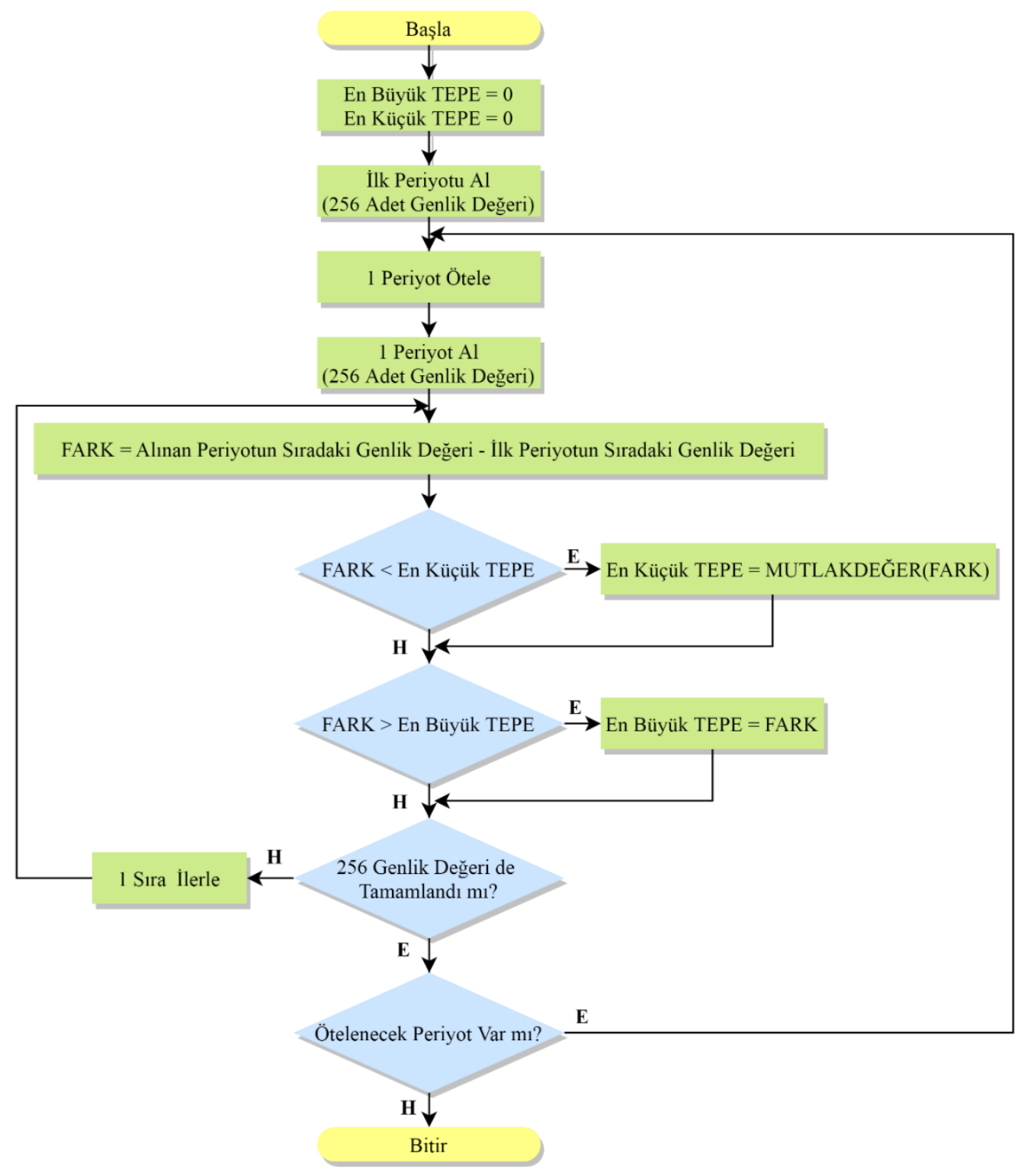

Şekil 8. En küçük ve en büyüktepe değerlerinin elde edilmesi algoritması 


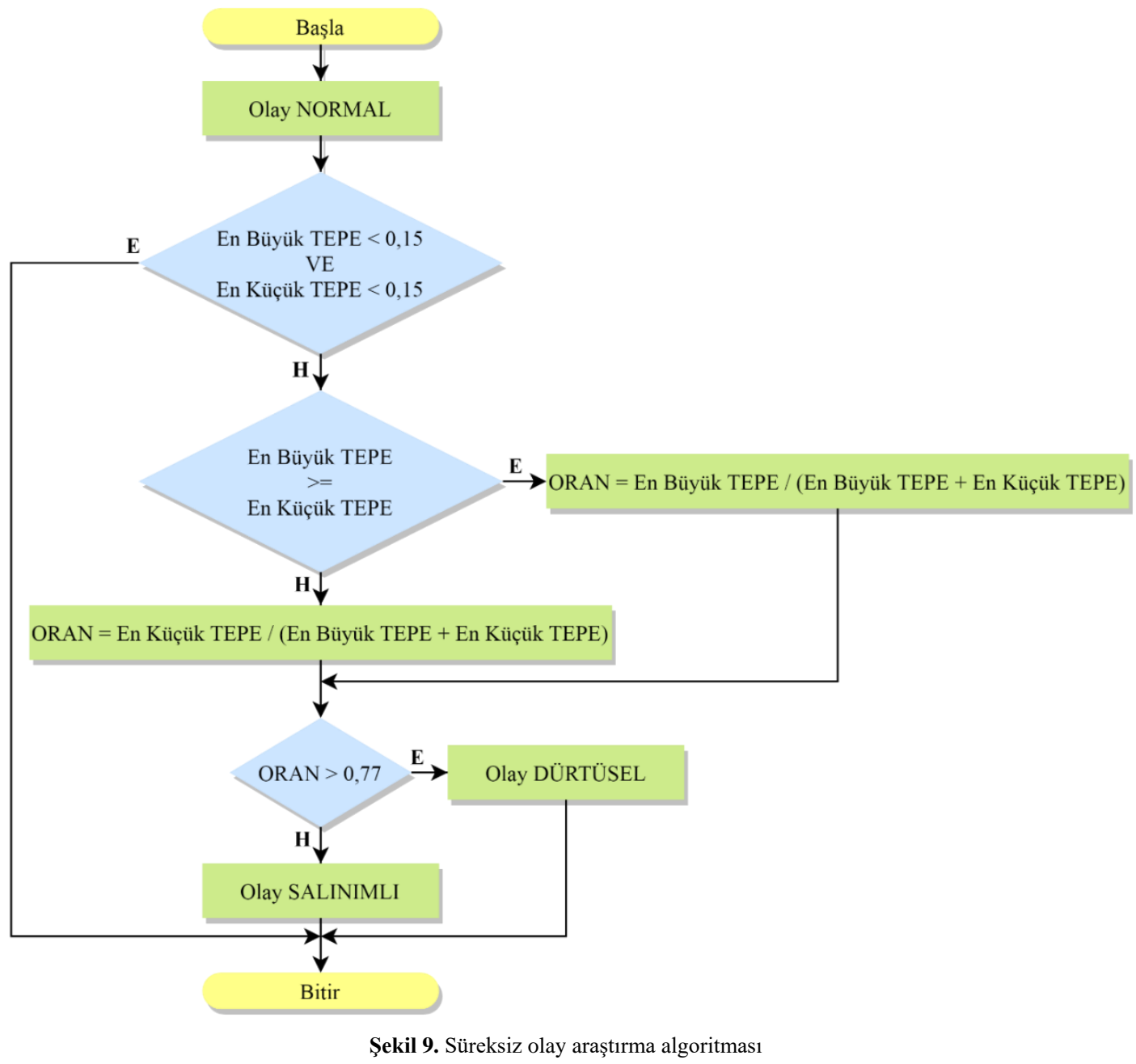

\section{BULGULAR VE TARTIŞMA}

“LabVIEW Veri Seti Doğrulama” uygulaması sonuçları Tablo 3 ve Tablo 4’te verilmiştir. Veri setinde her bir olay için 200 adet olay işareti bulunmaktadır. Sonuçlar incelendiğinde gürültüsüz veriler ile $50 \mathrm{~dB}$ ve 40 dB gürültülü verilerin sonuçlarının aynı olduğu görülmüştür. Tüm sınıflar mutlak başarıyla doğru etiketlenmiştir. "LabVIEW Veri Seti Doğrulama” algoritmasının gürültüsüz veriler, 50 dB düşük gürültü seviyeli ve $40 \mathrm{~dB}$ orta gürültü seviyeli verilerle mutlak başarıma sahip olduğu değerlendirilmiştir.

Tablo 3. Gürültüsüz,50 dB ve $40 \mathrm{~dB}$ gürültülü veriler için doğrulama sonuçları.

\begin{tabular}{c|ccccccc}
\hline Sınıf & Normal & Çökme & Kesinti & Şişme & Dürtüsel & Salınımlı & Doğruluk \\
\hline Normal & 200 & 0 & 0 & 0 & 0 & 0 & $\% 100$ \\
Çökme & 0 & 200 & 0 & 0 & 0 & 0 & $\% 100$ \\
Kesinti & 0 & 0 & 200 & 0 & 0 & 0 & $\% 100$ \\
Şişme & 0 & 0 & 0 & 200 & 0 & 0 & $\% 100$ \\
Dürtüsel & 0 & 0 & 0 & 0 & 200 & 0 & $\% 100$ \\
Salınımlı & 0 & 0 & 0 & 0 & 0 & 200 & $\% 100$ \\
\hline
\end{tabular}

Tablo 4'de verilen sonuçlar $30 \mathrm{~dB}$ yüksek gürültü seviyeli verilere aittir. Güç sistemi için $30 \mathrm{~dB}$ gürültü yüksek bir seviyedir. Bozulma olaylarından gerilim çökmesi, gerilim şişmesi ve gerilim kesintisi tespitinde algoritmanın yüksek gürültüden olumsuz etkilenmeden doğru sonuçlar elde ettiği görülmektedir. Olay içermeyen normal durumda ise $\% 1$ oranında hata ortaya çıkmıştır. Normal durumda hatalı tespit edilen olayların sadece 
salınımlı olay olarak etiketlendikleri görülmüştür. Buna sebep olan gürültü işaretinin bozucu etkisidir. Gürültü işaretinde pozitif ve negatif tepe değerlerinin salınımlı olay eşik değerlerini aşması, olay içermeyen işaretin salınımlı olay olarak etiketlenmesine neden olmaktadır.

Tablo 4'te verilen dikkat çekici diğer bir sonuç ise dürtüsel olayların yüksek oranda hatalı etiketlenmesidir. Yüksek gürültü seviyesinin bozucu etkisi en fazla dürtüsel olay türünün tespitinde kendini göstermiştir. Gürültü işaretinin dürtüsel olayı oluşturan işaretin zıt yönünde oluşması ile dürtüsel olay salınımlı olay olarak etiketlenmektedir.

Tablo 4. 30 dB gürültülü veriler için doğrulama sonuçları.

\begin{tabular}{c|ccccccc}
\hline Sınıf & Normal & Çökme & Kesinti & Şişme & Dürtüsel & Salınımlı & Doğruluk \\
\hline Normal & 192 & 0 & 0 & 0 & 0 & 2 & $\% 99$ \\
Çökme & 0 & 200 & 0 & 0 & 0 & 0 & $\% 100$ \\
Kesinti & 0 & 0 & 200 & 0 & 0 & 0 & $\% 100$ \\
Şişme & 0 & 0 & 0 & 200 & 0 & 0 & $\% 100$ \\
Dürtüsel & 0 & 0 & 0 & 0 & 123 & 77 & $\% 61,5$ \\
Salınımlı & 0 & 0 & 0 & 0 & 0 & 200 & $\% 100$ \\
\hline
\end{tabular}

\section{SONUÇLAR}

Bu çalışmada şebeke geriliminde meydana gelen bozulmalardan kısa süreli RMS değişimleri ve süreksiz olaylar incelenmiştir. Güç kalitesi olay işaretlerinin elde edilmesinde matematiksel denklemlere dayalı yöntem kullanılarak LabVIEW ile program tasarımı gerçekleştirilmiş̧tir. Bozulma olayı tespitinde gürültü önemli bir parametre olduğundan üretilen işaretlere çeşitli seviyelerde gürültü eklenmiştir. Gürültü eklenerek üretilen işaretlerin gerçek şebeke verilerine benzerliği artırlarak akademik çalışmalarda kullanılabilirliği sağlanmıştır. Bozulma olayı işaretlerinin tanımlarına uygun olarak üretilip üretilmediğini sınamak amacıyla algoritmalar geliştirilmiştir. Geliştirilen algoritmalar LabVIEW ile programlanarak olay işaretlerinin doğruluğu sınanmıştır.

Sınama sonuçları incelendiğinde yüksek gürültülü olay işaretleri hariç olmak üzere matematiksel modele dayalı üretilen veri setlerinin \%100 oranda doğru olarak etiketlendiği görülmüştür. Yüksek gürültülü veri setinin kısa süreli RMS değiş̧imine bağlı olaylarda da \%100 oranda doğru olarak etiketlendiği görülmüştür. Ancak gürültünün bozucu etkisi nedeniyle genliği düşük dürtüsel süreksiz olayların yapısının bozulduğu ve ancak \%61,5 doğrulukta etiketlendiği görülmüştür.

Sınıflandırmada, bazı dürtüsel süreksiz olayların salınımlı süreksiz olay olarak etiketlendikleri görülmektedir. Bunun nedeni gürültü işareti ile salınımlı süreksiz olay saf bileşeni dalga biçimlerinin karakteristik olarak benzer olmasıdır. Gürültünün bozucu etkisi süreksiz olaylarda sınıflandırma başarım oranını düşürmektedir. Gürültünün şebeke sinyallerinden ayrıştırılmasının ve/veya gürültü azaltma ve filtreleme yöntemlerinin kulanılmasının sınıflandırma başarım oranını yükselteceği değerlendirilmektedir.

\section{KAYNAKLAR}

[1] Ünsal, A., Von Jouanne, A. R., \& Stonick, V. L. (2002). A DSP controlled resonant active filter for power conditioning in three-phase industrial power systems. Signal Processing, 82(11), 1743-1752. doi:10.1016/S0165-1684(02)00335-3

[2] Ibrahim, W. A., \& Morcos, M. M. (2002). Artificial intelligence and advanced mathematical tools for power quality applications: a survey. IEEE Transactions on Power Delivery, 17(2), 668-673. doi:10.1109/61.997958

[3] Bollen, M. H. J. (2000). Understanding Power Quality Problems - Voltage Sags and Interruptions. IEEE PressSeries on Power Engineering - John Wiley andSons, USA,672.

[4] Sharma, A., Rajpurohit, B. S., \& Singh, S. N. (2018). A review on economics of power quality: Impact, assessment and mitigation. Renewable and Sustainable Energy Reviews, 88, 363-372. doi:10.1016/j.rser.2018.02.011

[5] IEEE Standard (Institute of Electrical and Electronics Engineers), (2009). Std 1159-2009 : IEEE Recommended Practice for Monitoring Electric Power Quality. doi:10.1109/IEEESTD.2009.5154067 
[6] Bath, S. K., \& Kumra, S. (2008). Simulation and measurement of power waveform distortions using LabVIEW. 2008 IEEE International Power Modulators and High-Voltage Conference, 427-434. doi:10.1109/IPMC.2008.4743681

[7] Yin, P. Y., \& Chilukuri, M. V. (2009). Remote power quality monitoring and analysis system using LabVIEW software. 2009 IEEE Instrumentation and Measurement Technology Conference, 279-283. doi:10.1109/IMTC.2009.5168459

[8] Laskar, S. H., \& Muhammad, M. (2011). Power quality monitoring by virtual instrumentation using LabVIEW. 2011 46th International Universities' Power Engineering Conference (UPEC), 1-6.

[9] Pradhan, D., Lakshminarayanan, L., \& Patii, V. (2014). A LabVIEW based power analyzer. 2014 International Conference on Advances in Energy Conversion Technologies (ICAECT), 67-71. doi:10.1109/ICAECT.2014.6757063

[10] Simić, M., Kokolanski, Z., Denić, D., Dimcev, V., Živanović, D., \& Taskovski, D. (2017). Design and evaluation of computer-based electrical power quality signal generator. Measurement, 107, 77-88. doi:10.1016/j.measurement.2017.05.010

[11] Simić, M., Živanović, D., \& Denić, D. (2012). Development of the signal generator applied to testing of instruments for electrical power quality measurement. Facta universitatis-series: Electronics and Energetics, 25(3), 193-201. doi:10.2298/FUEE1203193S

[12] Chunling, C., Huihui, Q., Wei, Z., \& Pengfei, W. (2012). Transient power quality signal generator and detector platform. Energy Procedia, 16, 1380-1385. doi:10.1016/j.egypro.2012.01.219

[13] Khadse, C. B., Chaudhari, M. A., \& Borghate, V. B. (2016). A laboratory set-up for power quality disturbance generator and real time power quality monitoring. 2016 IEEE International WIE Conference on Electrical and Computer Engineering (WIECON-ECE), 61-64. doi:10.1109/WIECON-ECE.2016.8009088

[14] Nadhiroh, N., \& Aji, A. D. (2019). Real-time monitoring of power quality for web based electrical power panel using LabVIEW. 2019 International Conference on Electrical Engineering and Computer Science (ICECOS), 217-221.doi:10.1109/ICECOS47637.2019.8984441

[15] Velkovski, B., \& Kokolanski, Z. (2020). A Virtual Signal Generator for Real-Time Generation of Power Quality Disturbances. In 2020 XXIX International Scientific Conference Electronics (ET), 1-4. doi:10.1109/ET50336.2020.9238243

[16] Dekhandji, F. Z., Talhaoui, S., \& Arkab, Y. (2019). Power Quality Detection, Classification and Monitoring Using LABVIEW. Algerian Journal of Signals and Systems, 4(2), 101-111. doi:10.51485/ajss.v4i2.86

[17] Subtirelu, G. E., Dobriceanu, M., \& Lincă, M. (2021). Virtual Instrumentation for Power Quality Analysis in the Main Supplying Point at Entrance of an Industrial Consumer. In 2021 International Conference on Applied and Theoretical Electricity (ICATE), 1-6. doi:10.1109/ICATE49685.2021.9465068

[18] Tan, R. H., \& Ramachandaramurthy, V. K. (2010). Numerical model framework of power quality events. European Journal of Scientific Research, 43(1), 30-47.

[19] IEC Standard (International Electrotechnical Commission), (2015). IEC 61000-4-30: Electromagnetic compatibility (EMC) -Part 4-30: Testing and measurement techniques - Power quality measurementmethods. 